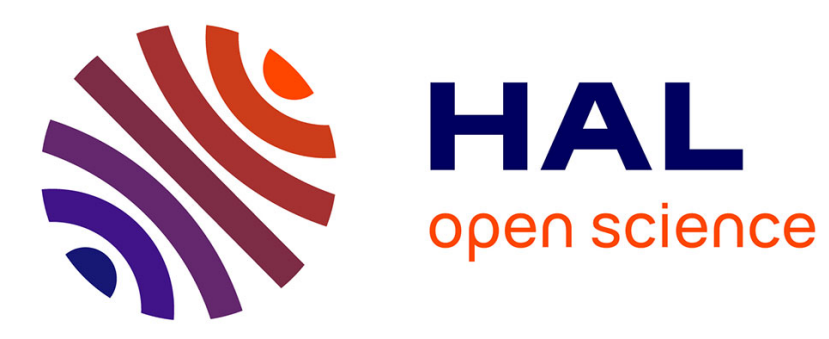

\title{
Energy for maintaining liveweight: an indicator of adaptive abilities of beef cows?
}

Anne de La Torre Capitan, Fabienne Blanc-Vazeille, Emilie Recoules, David Egal, Claire Agabriel

\section{- To cite this version:}

Anne de La Torre Capitan, Fabienne Blanc-Vazeille, Emilie Recoules, David Egal, Claire Agabriel. Energy for maintaining liveweight: an indicator of adaptive abilities of beef cows?. 4. EAAP International Symposium on Energy and Protein Metabolism and Nutrition (ISEP), Sep 2013, Sacramento, United States. 535 p. hal-02744652

\section{HAL Id: hal-02744652 \\ https://hal.inrae.fr/hal-02744652}

Submitted on 3 Jun 2020

HAL is a multi-disciplinary open access archive for the deposit and dissemination of scientific research documents, whether they are published or not. The documents may come from teaching and research institutions in France or abroad, or from public or private research centers.
L'archive ouverte pluridisciplinaire HAL, est destinée au dépôt et à la diffusion de documents scientifiques de niveau recherche, publiés ou non, émanant des établissements d'enseignement et de recherche français ou étrangers, des laboratoires publics ou privés. 


\title{
Energy for maintaining liveweight: an indicator of adaptive abilities of beef cows?
}

\author{
A. De La Torre ${ }^{1,2}$, F. Blanc ${ }^{2,1}$,E. Recoules ${ }^{1,2}$, D. Egal ${ }^{3}$, and J. Agabriel ${ }^{1,2}$ \\ ${ }^{1}$ INRA, UMR 1213 Herbivores, 63122 Saint-Genès-Champanelle, France. \\ ${ }^{2}$ VetAgro Sup, UMR 1213 Herbivores, 63000 Clermont-Ferrand, France. \\ ${ }^{3}$ INRA, UE1296 Monts d'Auvergne, 63210 Orcival, France.
}

\section{Introduction}

Productivity of low input livestock systems partly relies on animals' ability to cope with changing environments while achieving productive and reproductive performances. In such conditions, individuals' robustness could be estimated by indicators of animal adaptive abilities which account for energy variations across the productive cycle. In mature suckler cows, the net energy requirements for production are low (30\%) compared to those for maintenance $(70 \%)$ which complicates the evaluation of adaptive abilities. The later could be approached by estimating the net energy required for maintaining liveweight constant (Em). The objective of this study was to 1- estimate in beef cows having different body reserves at calving the partition of net energy between net energy outputs (Em, Emilk) and net energy inputs (Eintake + Etissues) and 2- test the relevance of Em as an indicator of adaptive abilities of beef cows.

\section{Material and methods}

Fourty multiparous charolais cows varying in body condition at calving (BCS scale from 0 to 5): 20 thin $(\mathrm{T}, \mathrm{BCS}=2.0 \pm 0.04)$ vs. 20 fat $(\mathrm{F}, \mathrm{BCS}=2.8 \pm 0.08)$ were submitted to a nutritional challenge consisting in a sequence of two contrasted feeding periods. During period 1 (P1), from calving to 120 days postpartum, cows were reared indoors and were fed the same basal diet according to two energy levels (Control, C vs Low, L). Intake expressed in $\mathrm{NE}$ for lactation $\left(\mathrm{NE}_{\mathrm{L}}\right)$ averaged 0.57 and $0.36 \mathrm{MJ} / \mathrm{d} / \mathrm{kg}^{0.75}$ for $\mathrm{C}$ and $\mathrm{L}$ cows. At the end of $\mathrm{P} 1$, all cows were turned out to a permanent pasture for a 76 days period (P2). Individual intakes at grazing were estimated from fill unit system (INRA, 2007). During P1 and P2, body weight, BCS and milk production were regularly measured. Body lipids were assessed by measuring subcutaneous adipose cell diameter at calving and at the end of P1 and P2. Em was calculated over P1 and P2. It was defined as follow Em = Eintake - (Emilk + Etissues), all terms expressed in Net Energy for lactation. Energy in milk was taken at $3.2 \mathrm{MJ} / \mathrm{kg}$ assuming a standard milk composition for beef cows (INRA, 2007). The tissue net energy conversion rate to milk production was taken as 0.8 . We assumed that the net energy value of a kilogram of body mass change is equal to $66.7 \mathrm{MJ} \times \mathrm{x} \%$ of lipids $+39 \mathrm{MJ} \times \%$ of fat-free mass (Garcia and Agabriel, 2007). Data were analyzed using PROC MIXED (SAS) including BCS at calving, postpartum energy levels and days as fixed effects and individual as random effect.

\section{Results and discussion}

\begin{tabular}{|l|l|l|l|l|l|l|l|l|l|l|}
\hline & \multicolumn{4}{|c|}{ Period 1 (indoors) } & \multicolumn{5}{c|}{ Period 2 (pasture) } \\
\hline & FC & FL & TC & TL & SEM & FC & FL & TC & TL & SEM \\
\hline Milk (kg/day) & 8.3 & 8.7 & 9.2 & 7.0 & 0.6 & 6.0 & 6.8 & 7.6 & 7.1 & 0.5 \\
\hline ADG (kg/day) & 0.8 & 0.9 & 0.9 & 0.7 & 0.09 & 1.1 & 1.2 & 1.1 & 1.1 & 0.10 \\
\hline LW start(kg) & $846^{\text {ab }}$ & $852^{\mathrm{a}}$ & $761^{\mathrm{ab}}$ & $753^{\mathrm{b}}$ & 17.4 & $827^{\mathrm{a}}$ & $790^{\mathrm{ab}}$ & $734^{\mathrm{ab}}$ & $716^{\mathrm{b}}$ & 17.8 \\
\hline LW end (kg) & $834^{\mathrm{a}}$ & $810^{\mathrm{ab}}$ & $762^{\mathrm{ab}}$ & $719^{\mathrm{b}}$ & 17.9 & 805 & 824 & 767 & 776 & 18.2 \\
\hline ACD change & $-4.5^{\mathrm{a}}$ & $-9.6^{\mathrm{b}}$ & $2.6^{\mathrm{a}}$ & $-10.0^{\mathrm{b}}$ & 2.0 & 7.5 & 11.2 & 0.93 & 3.4 & 1.6 \\
\hline
\end{tabular}


Table 1: Effect of body condition at calving and postpartum energy level on milk production, average daily gain of calves $(A D G)$, liveweight $(L W)$ and adipose cells diameter $(A C D)$.

Over the whole experimental period, average milk production and calf body weight gain were similar between the four groups. Over P1, FL and TL cows lost $43 \pm 13$ and $25 \pm 17 \mathrm{~kg}$ compared to $\mathrm{FC}$ and $\mathrm{TC}$ cows, respectively. L treatment resulted mainly in a fat mass loss, whereas $\mathrm{C}$ treatment induced no (FC) or only a slight (TC) weight gain which was mostly due to an increase in fat mass (99 MJ). These discrepancies resulted in differences in net energy balance (Figure 1). Decreasing Eintake led to a decrease in Em, which was $25 \%$ lower in L vs $\mathrm{C}$ level of energy intake $(P<0.05)$. At the end of P2, FL and TL cows weighed 20 and $10 \mathrm{~kg}$ less than FC and TC cows, respectively. Over P2, Em remained lower in cows previously submitted to energy restriction in comparison to $\mathrm{C}$ cows $(P<0.05)$. This result is related to a compensatory rebound which is associated to lower Em after a period of nutritional restriction (Hornick, 2000). It is the lag time in adaptation of Em before its gradual increase which gives to the restricted cows the ability to recover weight loss and condition without affecting milk production. Much of Em variation with energy level is related to rapid changes in visceral mass and energy expenditures (Ortigues et al., 1993, Freetly et al., 1998).

Thus, the ability of cows to mobilize and recover body reserves under restriction/refeeding periods provides them the adaptive ability to low net energy for maintaining liveweight constant. The lag time in adaptation of Em as a result of the feeding restriction is partly the support of cows' adaptation at least at short and medium term. The long term effects of adaptation should be further investigated. Variations in Em can be so interpreted as an indicator of the ability of mature producing cows to face nutritional constraints.

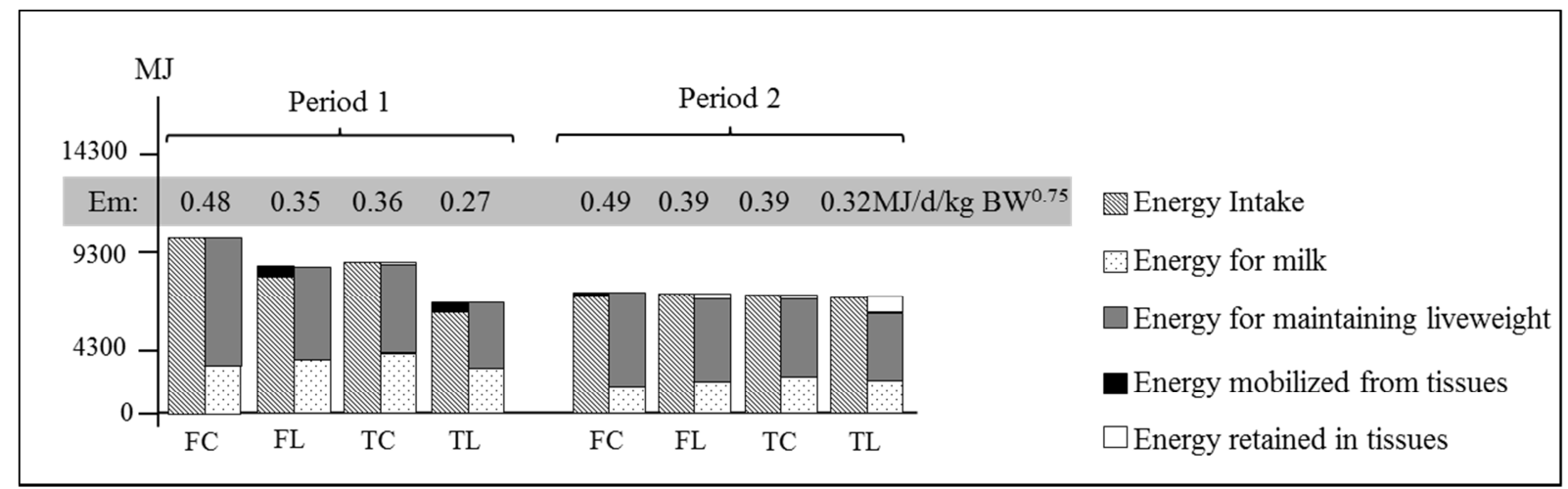

Figure 1: Effect of body condition at calving and postpartum energy level on energy balance and partition during the initial indoors (1) and pasture (2) periods.

\section{References}

Freetly H., J. Nienaber and T. Brown-Brandl, 1998. Efficiency of energy and nitrogen loss and gain in mature cows. Journal of Animal Science, 76, 896-905.

Garcia F. and J. Agabriel, 2007. Update of feeding recommendations for fattening of culled cows. Development of a model for the estimation of the composition of weight gain and associated requirements. Productions Animales, 20, 137-149.

INRA 2007. Alimentation des bovins, ovins et caprins. Besoins des animaux - valeurs des aliments, Quae (Ed), Versailles

Hornick J., C. Van Eename, A. Clinquart, O. Gerard and L. Istasse, 2000. Mecanism of reduced and compensatory growth. Domestic Animal Endocrinology, 19, 121-132.

Ortigues I., M. Petit, J. Agabriel and M. Vermorel, 1993. Maintenance requirements in metabolizable energy of adult non pregnant non lactating Charolais Cows. Journal of Animal Science, 71, 19471956.

SAS, 2009. Release 9.2. SAS Inst. Inc, cary, NC, USA. 